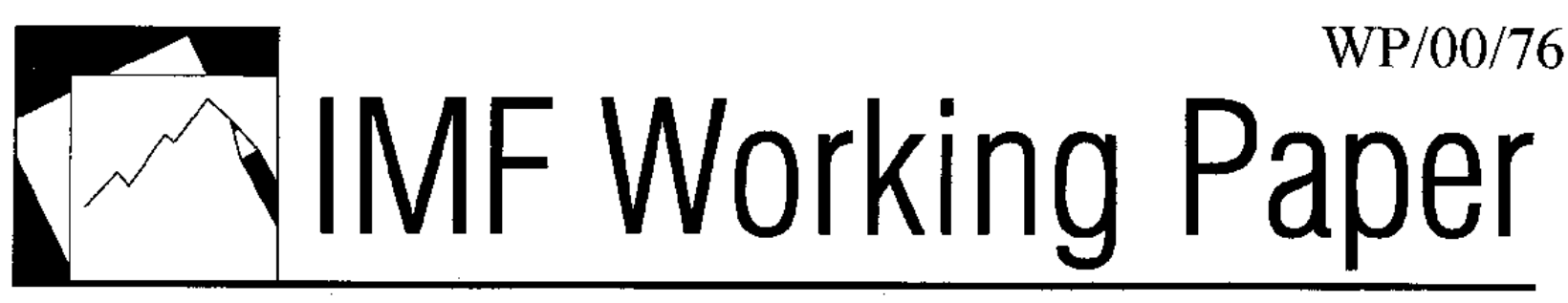

\title{
Assessing Financial System Vulnerabilities
}

\author{
R. Barry Johnston, Jingqing Chai, and \\ Liliana Schumacher
}


IMF Working Paper

Monetary and Exchange Affairs Department

Assessing Financial System Vulnerabilities

Prepared by R. Barry Johnston, Jingqing Chai, and Liliana Schumacher ${ }^{1}$

April 2000

\begin{abstract}
The views expressed in this Working Paper are those of the author(s) and do not necessarily represent those of the IMF or IMF policy. Working Papers describe research in progress by the author(s) and are published to elicit comments and to further debale.
\end{abstract}

Recent financial crises have highlighted the potentially significant macroeconomic costs of financial system instability, and the potential for the instability in the financial system of one country to have broader implications for the stability of financial systems and macroeconomic performance in other countries. This paper reviews the different analytical approaches to assessing vulnerabilities in the financial systems and the benefits and limitations of the different approaches, and suggests enhancements that could help strengthen financial system stability assessments.

JEL Classification Numbers: G15, B40, C4

Keywords: asymmetric information, incentive structure, risk models, financial system vulnerabilities

Author’s E-Mail Address: bjohnston@imf.org; jchai@imf.org; 1schumacher@imf.org

\footnotetext{
${ }^{1}$ The authors acknowledge the contributions and comments of Stefan Ingves, Jahanara Begum, Tito Cordella, Karl Driessen, Luca Errico, Edward Frydl, Haizhou Huang, and Matthew Jones.
} 
I. Introduction and Summary $\quad 4$

II. Economic Theories of Financial System Vulnerabilities $\quad 7$

A. Sources of Instability in Financial Markets............................................... 7

B. Applying the Insights from the Economic Theories ..................................... 9

Institutional structure ................................................................ 10

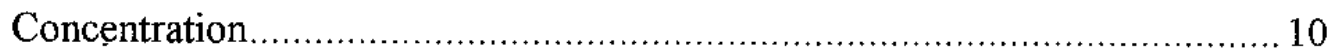

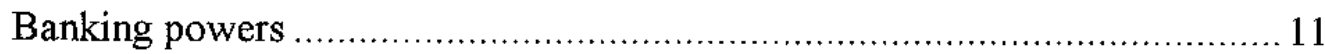

Corporate governance .............................................................. 11

Ownership and bank liabilities structure ........................................... 11

Market incentives to monitor behavior ................................................ 12

Supervisory incentives to monitor behavior .................................... 12

Financial liberalization and instability ........................................... 12

Explicit and implicit guarantees .................................................... 13

C. Investigating "Structural" Weaknesses in the Financial System ....................... 13

D. Financial Safety Nets .................................................................... 15

III. Techniques for Assessing Risks in the Financial System 16

A. Principal Types of Financial Risks ..................................................... 16

B. Balance Sheets and Macroprudential Indicators and their Limitations ................ 17

C. Risk Measurement Models ........................................................................ 19

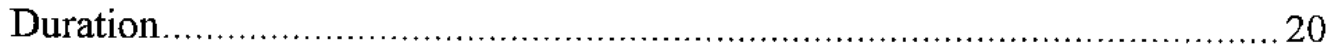

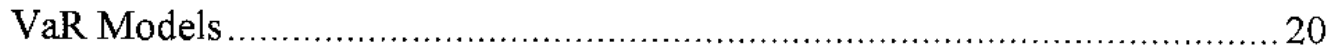

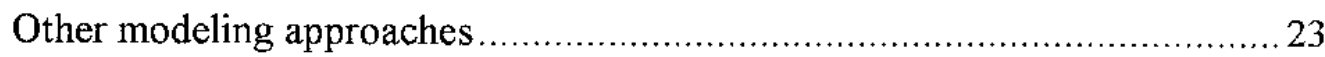

D. Evaluation of Risk Measurement Models ................................................ 24

Use of models by the industry ....................................................... 24

Use of models for assessments of financial system vulnerability ................ 25

Need for additional research........................................................ 26

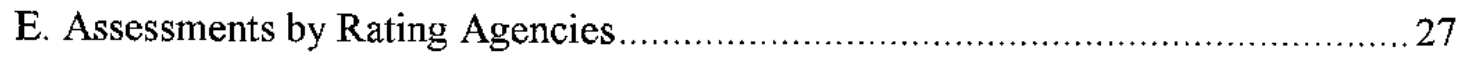

IV. Supervisory Assessments and Systemic Vulnerabilities 27

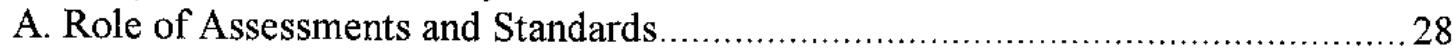

B. Methodology for Assessing Financial System Vulnerabilities......................... 29

V. Conclusions and Directions for Further Research 31

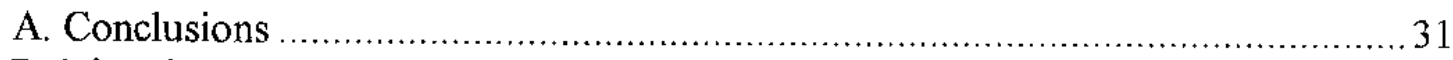

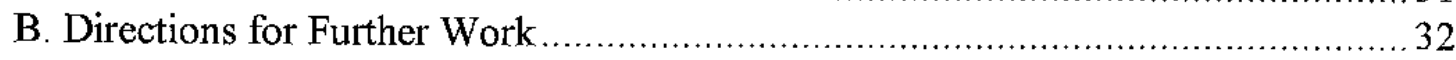


Appendices

Duration Models

References

Figures

1. Systemic Vulnerability Matrix.

\section{Text Tables}

1. Synoptic Comparison of Main Features of Polar Financial Systems.

2. Investigation of Structural Weaknesses in the Financial System 15

3. Possible Macroprudential Indicators 


\section{INTRODUCTION AND SUMMARY}

Recent financial crises have highlighted the potentially significant macroeconomic costs of financial system instability, and the potential for the instability in the financial system of one country to have broader implications for the stability of financial systems and macroeconomic performance in other countries. Against the backdrop of deep concerns of the international community for such potentially significant macroeconomic costs, the Fund has recently embarked on a Financial Sector Assessment Program (FSAP) in collaboration with the World Bank, and Financial System Stability Assessments (FSSAs) in the context of its Article IV surveillance of members economies. ${ }^{2}$ These assessments seek to identify, inter alia, potential vulnerabilities in financial systems that could have significant macroeconomic consequences.

The purpose of this paper is to review the different analytical approaches to assessing vulnerabilities in the financial systems; to review the benefits and limitations of the different approaches; and to suggest enhancements that could help strengthen financial system stability assessments.

A modern financial system encompasses a large number of institutions, markets, and agents, and is exposed to a variety of potential sources of vulnerability: ${ }^{3}$

- The first type of vulnerability is associated with the non-diversified risks on and off the balance sheets of individual institutions, normally classified as credit risk, market risk, liquidity risk, and operational risk. There is an increasing recognition that these risks are interrelated-that market risk is closely associated with liquidity risk, and credit risk is associated with both types of risks. The first type of vulnerability is associated with potential losses and failures in individual institutions and markets.

- The second type of vulnerability concerns the vulnerability of the financial system as a whole - systemic vulnerability. The mapping of weaknesses in individual institutions and markets to system-wide vulnerabilities requires an examination of the functioning of the financial system as a whole. System-wide vulnerabilities are associated, for example, with contagion risks when disturbances in one market or financial institution spill over into other markets and financial institutions, exposing

\footnotetext{
${ }^{2}$ See G-7 Finance Ministers Communique on the Global Financial Structure, Cologne, Germany, June 1999.

${ }^{3}$ Generally, a modern financial system will include various types of deposit-takers (banks and credit agencies); money, bond, and foreign exchange markets; securities exchanges and firms; insurance, pension, and wealth-management companies (including mutual funds); payments and clearing systems; and, in more developed systems, derivative markets. The financial system also encompasses the central bank, supervisory bodies, financial safety nets, and the financial regulatory framework.
} 
the institutions to gains and losses in markets not subject to the initial disturbances. System-wide vulnerabilities may be associated with multiple equilibria, such as when small shocks lead to large movements away from the original equilibrium, and with full-blown financial crises, that can have significant macroeconomic, as well as serious financial sector implications.

- A financial system can be considered vulnerable to crisis where it is not readily able to absorb shocks. These shocks include price (interest rate, exchange rate, commodity, etc.) and liquidity (access to market) shocks; shocks to credit quality and the macroeconomic environment; and shocks to the financial institution structure (e.g., arising from the evolution of financial markets and instruments, changes in the regulatory framework, or shifts in supply and demand for assets).

An assessment of the potential vulnerabilities in the financial system requires an examination of a range of factors, including the balance sheet positions of the different agents; the sophistication of the risk-management systems in the individual institutions; the degree of development of financial markets where risks can be managed; the types of incentive structures confronting different agents; the prudential margins for safety provided by the supervisory and regulatory framework (such as the minimum capital standards); and the system of financial safety nets and crisis management. For the purpose of analyzing the different elements involved in assessing financial system vulnerabilities, we have classified them under the following categories:

1. An economic or incentive structure approach that focuses on underlying sources of vulnerabilities in financial systems as identified in the theoretical economic literature. This approach emphasizes the implications of asymmetric information for identifying factors affecting incentive structures and potential sources of "structural" vulnerability in the financial systems;

2. A risk-assessment approach that seeks to quantify the risks and exposures in individual financial institutions. Certain risk-measurement techniques, including a number of macroprudential indicators and stress tests, are designed to identify and to some degree quantify the immediate, salient vulnerabilities in the financial institutions;

3. A supervisory approach that emphasizes the adequacy of the supervisory framework in which the assessment of international standards and best practices plays a role. The supervisory approach helps to determine whether the supervisory system is adequate to address the risks confronting the financial system; and

4. A systemic vulnerability assessment, or what we have termed an assessment of "net risk," seeks to compare the risks confronting the financial system with the capacity of the system to manage those risks at the level of the financial systems as a whole. Systemic assessments recognize the interdependence of macroeconomic performance and soundness of the financial system. 
The main findings can be summarized as follows:

- An assessment of the near-term vulnerabilities in the financial system, will involve elements of the risk-assessment and supervisory approaches to identify the vulnerabilities at the level of the financial institutions. An assessment of systemic vulnerabilities in the financial institutions requires a comparison of the potential risks (as identified through the risk-assessment approach), with the capacity of the financial institutions to manage those risks. The difference between the risks and the capacity of the system to manage those risks could be viewed as the net risk in the financial institutions. Assessments of compliance with international standards and best practices in the financial system will be an element of these assessments; however, an assessment of the capacity of financial institutions to manage risk will have to go beyond a standards assessment, and be tailored to the circumstances of the country concerned.

- $\quad$ An assessment of the medium-to longer-term vulnerabilities, will require an identification of the possible economic sources of vulnerabilities in the financial system (asymmetric information, incentive structures, etc.). Risk-assessment approaches can identify the short-term vulnerabilities in the financial system, but they are only a snap shot, and do not generally determine how the system would evolve in response to a shock. The speed with which the conditions in the financial system can deteriorate in response to shocks may be gravely aggravated when there are distortions in the incentive structures under which financial agents operate. Given the likely infrequency of comprehensive financial system assessments and the difficulty of predicting shocks to the financial system, it will be important also to focus on the potential structural weaknesses in the financial system. The main elements involved in an assessment of the structural weaknesses include: (i) an assessment of the integrity of the underlying legal and institutional environment, including the integrity of financial information; (ii) the ownership and governance structure of financial institutions; (iii) the bank regulatory environment; and (iv) the existence of explicit and implicit public sector guarantees.

- An assessment of the different risk-measurement techniques, concludes that riskmeasurement models are to be preferred over simple risk indicators. However, to be effective, risk-measurement models often require proprietary information related to bank and client positions that is usually regarded as highly confidential, and financial institutions may decide not to disclose it. Risk-model-based assessments are likely thus to depend on the willingness of banks to disclose confidential information. In the absence of such information, the financial system assessments could evaluate the methodologies used by banks to measure market, liquidity, and credit risk, and the capacity of the managers to properly manage risks. Lacking information on this, the assessments could evaluate the banking regulations and the ability of the bank supervisory agency to monitor the risk management process in the banks under their surveillance. 
The paper concludes that in view of the complexity of the issues involved in assessing financial system vulnerabilities, such assessments need to be based on a systematic analytical framework. For this purpose, it is suggested that:

- $\quad$ First, the FSSAs contain an overall financial stability assessment. These assessments could be made explicit in the form of "net risk" assessments in the financial systems, by drawing up an inventory of the principal sources of risk and comparing it with the capacity of the system to manage these risks;

- Second, assessments should explicitly examine a checklist of features and follow a systematic investigation methodology (an "incentive audit") to identify weaknesses in the incentive structures under which financial systems operate; and

- Third, there is a need for research on the methodologies for linking risk exposures with macroeconomic performance, recognizing the likely data limitations under which these assessments would be made.

The rest of this paper is organized as follows: Section II examines the economic theories of vulnerabilities in the financial system; Section III examines the techniques for assessing risks in the financial system; and Section IV reviews the role of supervisory assessments and discusses the assessment of systemic vulnerabilities. Section V concludes with suggestions for ways to strengthen financial system assessments.

\section{ECONOMIC THEORIES OF FINANCIAL SYSTEM VULNERABILITIES}

The economics literature on financial intermediation provides a framework for classifying and analyzing the fundamental nature of financial systems, based on the information that is available to the various participants. This section presents an overview of the economics theories, discusses how they could be applied as part of financial system assessments, and discusses the relationship between financial safety nets and instability.

\section{A. Sources of Instability in Financial Markets}

Financial intermediaries arise as a particular solution to the problem of asymmetric information: a situation in which one party to a financial transaction has superior information to another, because it is costly to gather information. Intermediaries can acquire specialized knowledge that enables them to screen projects and monitor agents at lower costs. Nevertheless, financial intermediaries have less than perfect information and thus while they can reduce the problem of asymmetric information, they do not eliminate it. Ignorance or absence of adequate screening of borrowers are often cited as sources of banking problems. The institutional form of intermediaries comes at a price: intermediary assets are typically less liquid than their liabilities, making them vulnerable to runs.

The potential problems caused by asymmetric information are generally classified into the following categories: 
Adverse selection occurs when agents with the greatest potential risks are more likely to enter into arrangements that reduce their risk. Because of asymmetric information, the counterpart to the arrangement does not have the same information on the risks the agent faces and cannot adequately assess those risks. The counterpart faces a screening problem to try and induce the agents to reveal their information and avoid having an "adverse selection" of agents with whom it transacts.

Moral hazard arises when agents do not bear the full costs or benefits of their actions and thus have the incentive to assume additional risk.

Free-rider problems, where an agent that collects information about a particular risk is unable to prevent other agents from using that information, and is thus unable to appropriate the full benefits of collecting the information. Adverse selection, moral hazard, and the free-rider problem can impair the efficient operation of the financial system, since agents are unable to price risk accurately.

Principal-agent and monitoring problems, where a principal cannot observe perfectly the actions of the agent to whom the principal delegates a certain activity or responsibility. Applications of principal-agent models include situations where shareholder interests differ from bondholders in the choice of risk in projects; situations where management interests differ from shareholder interests in investment decisions; and situations where banks differ from regulators on the riskiness of loans in the presence of deposit insurance. Principal-agent problems arise, for example, where managers acting in the shareholders' interests have an incentive to take excessive risks at the expense of debtholders (depositors). The depositors thus bear the downside risk while the shareholders benefit from the upside potential.

Rational herding, under which agents react to information on the decisions of other agents in the market rather than information on the underlying transactions themselves. Rational herding is built on the following features: (a) payoff externalities, where the payoffs to an agent adopting an action increase with the number of agents adopting the same action; and (b) information externalities or cascades, where agents gain useful information from observing previous agents' decisions to the point where it is optimal to ignore their own private information. Herding can arise where each manager prefers to mimic the actions of other managers, ignoring private information. For example, managerial performance is often based on relative and not absolute performance.

Contagion, where a shock in one asset market affects prices in other asset markets. Contagion occurs because investors are not all informed about the risks, and, thus cannot distinguish cross-market hedging from information-motivated sales. Much of the contagion literature has focused on explaining the transmission of financial crises across countries through factors such as financial market correlation, similarity of macroeconomic characteristics, trade spillovers (due to depreciation in the crisis country), and contagion from 
investor behavior (e.g., investors may cover losses in the crisis country by reducing their overall exposure to emerging markets). ${ }^{4}$

There are numerous examples in theory and practice where the above problems result in financial vulnerability. For example, a typical discussion of the impact of unsound banks on the volume and efficiency of intermediation reflects the problems of adverse selection, moral hazard, monitoring, herding, and contagion. An unsound bank may continue lending to unprofitable enterprises or to insolvent debtors to prevent defaults that would in turn result in open insolvency of the bank; or the insolvent bank may lend to high-risk borrowers in an effort to "gamble for resurrection." The availability of bank credit will be reduced where depositors are unable to distinguish between sound and unsound financial institutions and markets and shift their funds into cash or other government-backed financial instruments, or overseas. Increased uncertainty associated with financial sector problems would be associated with an increase in risk premiums that lowers the expected rate of return of real assets, with negative effects on asset prices, collateral values, private wealth and expenditures, and output. A loss of confidence in the domestic financial system may be associated with capital flight, as investors look for safe heavens abroad.

Another example is the seminal work on bank runs, as set forth in Diamond and Dybvig (1983) model. Their model has two salient features. First, investors can see (through long lines) when other investors are running the bank. Second, when banks that have invested in long-term projects are forced to liquidate early because of the run, there is a potential shortfall of funds. Hence, the last depositor to withdraw may be left empty-handed. Diamond and Dybvig show that there are two feasible equilibria: one where a bank remains solvent to pay off high returns to all participants, and the other ("run" equilibrium) where every investor correctly believes that other investors' withdrawals are forcing the bank to short-sell its high-profitability investment.

Typically, the problems caused by asymmetric information are worsened when there are shocks to the financial system, that make it more difficult to distinguish the "signal from the noise." This creates the problem that in some circumstances small shocks can be destabilizing.

\section{B. Applying the Insights from the Economic Theories}

Applying the insights from the economic theories in assessing financial sector vulnerabilities will generally require an assessment of the structural features of the economy that affect the incentives to screen and monitor risks. At the operational level, this is likely to involve a review of the institutional structure, the legal and regulatory system, corporate governance, the nature of implicit and explicit guarantees, and the nature of shocks to the financial system from financial sector reform.

\footnotetext{
${ }^{4}$ See Masson (1999) for a survey of the literature.
} 


\section{Institutional structure}

There are different institutional organizations of banking systems that give rise to different monitoring systems. Typically, a distinction is made between "market-based" and "institution-based" systems. A comparison of the main features of market-based financial systems (e.g., the U.S. and U.K.) and institution-based financial systems (e.g., Japan and Germany) is provided in Table 1. Since the nature of the monitoring systems are quite different under these two systems (the first relies to a much greater extent on market disclosure and discipline than the latter), an assessment of adequacy of the information dissemination and monitoring systems should take account of the organizational structure of the banking system. For example, private information-gathering would take on greater significance under institutional-based systems, while public disclosure would be a key concern under market-based financial systems. Table 1 also identifies state-directed financial systems which can raise a host of non-market incentive structures in the allocation of credit and in the monitoring of performance.

Table 1. Synoptic Comparison of Main Features of Polar Financial Systems

\begin{tabular}{|l|c|c|c|c|c|}
\hline & \multicolumn{2}{|c|}{ Market-Based Systems } & \multicolumn{2}{|c|}{ Institution-Based Systems } & $\begin{array}{c}\text { State-Directed } \\
\text { Systems }\end{array}$ \\
\hline Fcatures & U.S. & U.K. & Japan & Germany & Pakistan \\
\hline $\begin{array}{l}\text { Role in allocation of } \\
\text { financial resources } \\
\text { *Financial markets } \\
\text { *Banks }\end{array}$ & $\begin{array}{c}\text { Primary role } \\
\text { Secondary role }\end{array}$ & $\begin{array}{c}\text { Primary role } \\
\text { Secondary role }\end{array}$ & $\begin{array}{c}\text { Secondary role } \\
\text { Primary role }\end{array}$ & $\begin{array}{c}\text { Marginal role } \\
\text { Dominant } \\
\text { role }\end{array}$ & $\begin{array}{c}\text { Minimal role } \\
\text { Dominant role }\end{array}$ \\
\hline $\begin{array}{l}\text { Concentration in the } \\
\text { banking industry }\end{array}$ & Low & High & High & High & High \\
\hline Banking model & $\begin{array}{c}\text { Specialized de } \\
\text { jure } \\
\text { (Glass-Steagall } \\
\text { Act) }\end{array}$ & $\begin{array}{c}\text { Specialized de } \\
\text { facto } \\
\text { (tradition) }\end{array}$ & Universal & Universal & Specialized \\
de jure
\end{tabular}

\section{Concentration}

The size and concentration of the banking system can affect the incentives for banks to take risks. More competitive financial systems reduce the franchise value of the banks and thus increase the incentives for managers working on behalf of share holders to take on more risks at the expense of debt holders and depositors. On the other hand, more concentrated systems may have less scope to diversify risks and may be more subject to contagion risks, 
especially where the markets do not differentiate between the major banks in terms of their solvency and business activities.

\section{Banking powers}

The nature of banking powers - universal banking versus specialized banking — can affect banks' incentives to monitor customers. Universal banks, that are well diversified, may not find it worthwhile to bear the cost of monitoring certain classes of borrowers or business activities and may have a greater tendency to free-ride on the monitoring and reputation of other lenders compared to specialized banks that are not as well diversified. Large money center banks' willingness to take on exposures to hedge funds prior to the LTCM crisis may be a case in point. State directed banks have less incentives to monitor creditors where (a) the loans are provided at the discretion of government; and (b) losses of the bank are explicitly guaranteed.

\section{Corporate governance}

A main bank system (a borrower has a principal long-term lender) and an arm'slength system (a borrower has a project-specific syndication of many banks) creates different incentives for both banks to monitor and the borrowers to reveal information and service their debts. In a main bank system, the value the borrower places on maintaining a long-term relationship with its bank provides an incentive to the borrower to reveal information. The access of main banks to the board of directors of the borrowing company can also give them increased access to information. On the other hand, arm's-length banking has an advantage in controlling moral hazard by increasing the penalties for nonservicing of the debt, since banks in a syndicate will have greater difficulty in cooperating to restructure a loan, and thus imposing a harder budget constraint on the borrower. Also, any given arm's-length bank can walk away without losing an investment in a long-term relationship.

\section{Ownership and bank liabilities structure}

The structure of ownership and the structure of bank liabilities affect the incentives for owners and creditors of banks to monitor bank behavior. Outside shareholders face a well-known principal-agent problem vis-à-vis management. The exact implications will likely depend, however, on the incentive structure created by the nature of executive compensation. Thus, for example, if managers personally participate little in the rewards of risk-taking but suffer its losses, say, through dismissal, they may take on less risk than equity holders desire. Alternatively if managers are compensated in terms of the returns on equity, this may encourage managers to take on excessive risk and to economize on equity capital. The latter may involve various types of capital regulatory arbitrage to meet Basel capital minimums with the minimum shareholder equity-such as through securitization of assets. This conflict and the monitoring problem may be magnified when outside shareholdings are disbursed and, therefore, passive.

Holders of nonequity liabilities have an incentive to discipline banks against risktaking, but they are often weak in exerting control. The more concentrated the holdings of 
deposits in the hands of knowledgeable holders, the stronger a force deposit-holders will be in controlling risk. A deposit insurance agency, with authority to establish minimum prudential standards can serve this function in some systems.

\section{Market incentives to monitor behavior}

For market participants, the monitoring of financial institutions is dependent upon the provision of timely and accurate information. This would in turn require suitable accounting standards and practices and disclosure requirements, and would be bolstered by ratings from rating agencies. However, market participants will only have an incentive to monitor the activities of financial institutions if they face the possibility of incurring losses. Thus containing implicit and explicit guarantees is a critical element in strengthening the incentives to monitor. To strengthen the incentives to monitor, some argue for an expanded role for subordinated debt by requiring that it be made a necessary component of regulatory capital, on the grounds that subordinated debt holdings are more concentrated than deposits and not insured, and thus subordinated debt holders have greater incentives to exert active control over the banks.

\section{Supervisory incentives to monitor behavior}

For supervisory authorities, the incentives to monitor result from appropriate legal authority and independence from political influences, and a regulatory framework that is based on clearly established legal principles, statutes, and defined roles for difficult regulators. Having well-defined rules and procedures for handling regulatory infractions and problem institutions can help minimize regulatory forbearance and clarify the "rules of the game" facing financial intermediaries. An example of this approach is the "prompt corrective action" framework, whereby a sequence of specific structured actions is automatically triggered whenever the performance of the intermediary falls below a certain threshold. The supervisor's incentives will also be influenced by the clarity of roles and transparency of functions and actions, as well as by the compensation package and the overall competence and adequacy of the staffing of the supervisory agency.

\section{Financial liberalization and instability}

Liberalization amounts to a radical change in the policy environment in which institutions operate, and brings with it new risks and new opportunities. Financial liberalization typically consists of the removal of government controls on interest rates, the admission of new entrants into the financial system (foreign and/or domestic), and the reduction of direct government ownership and control over intermediation, all of which can rapidly change the underlying incentive structures. In the aftermath of financial liberalization, franchise values have fallen as new entrants increased competition and reduced profitability, and as a consequence financial institutions have engaged in riskier activities. In a post-liberalized world, regulators are unable to use the old tools of analysis or control, and may be slow to respond to innovation; many regulators may leave the official sector for the rapidly increasing salaries available in newly deregulated financial systems. Consequently, the quality of supervisory oversight is also weakened. 


\section{Explicit and implicit guarantees}

One of the key lessons from the Asian crisis was the potentially seriously distorting and destabilizing effects of explicit or implicit exchange rate guarantees that market participants assumed would be available. These guarantees eliminated the incentives for foreign banks to monitor, and led to an underestimation of exchange rate risk, and increased the volatility of capital flows.

\section{Investigating "Structural" Weaknesses in the Financial System}

Currently, regulatory framework and practices do not take account of incentive structures in any systemic way. The Basel Committee on Banking Supervision, for example, has included market discipline as one of the three "pillars" of its regulatory framework (capital requirements and supervision are the other two), but has emphasized only enhanced transparency and increased disclosure as the regulatory support for market discipline. In fact, in a recent report the Committee states, "it is not within the authority of bank supervisors to ensure that all incentives for market discipline are in place." The structure of incentives within the financial sector, particularly with regard to risk-taking, is generally ignored within that framework.

One way of evaluating structural factors affecting the incentives for risk-taking in the financial sector, would be to include a report on incentive structures - an incentive audit-as part of the assessment of vulnerability in the financial system. Such a report could be built on a checklist of features similar to those outlined above-contract design, banking powers, banking relationships, structure of ownership and liabilities, industrial organization, existence of guarantees, and the adequacy of safety nets. The aim of the report would not be to endorse any particular structural feature, say, universal banking, as clearly superior in promoting financial stability, but to offer a systematic framework based on research on what incentives are generated by applicable structural features and how the regulators and other authorities have dealt with them. This assessment would help determine how regulation supports effective market discipline in member countries and taking on the role of "monitor of monitors" can fill some of the gap in the current framework pertaining to market discipline and incentive structures. The checklist would also offer a framework for making requests for

data sets--e.g., distribution of equity ownership of banks, industry concentration measures and entry and exit rates - that would be useful in developing further research on these issues.

An investigation of potential "structural" weaknesses in the financial systems, might be conducted in a sequential manner. Information would be gathered on an initial core set of issues that are known to affect the financial incentive structures-the nature of ownership of financial institutions, the existence of guarantees, etc. Based on the answers to these initial questions, a second level of issues would then need to be addressed to determine the significance of the initial findings for vulnerability in the financial systems. Table 2 provides an example. Third and fourth level issues might also need to be addressed. This type of methodology could help provide a road map to focus the assessment on the potential sources of vulnerability as guided by experience and economic theory. 
Table 2. Investigation of "Structural" Weaknesses in the Financial System

\begin{tabular}{|c|c|c|}
\hline Level 1 Questions & & Level 2 Questions \\
\hline $\begin{array}{c}\text { Nature of ownership structure of } \\
\text { financial institutions }\end{array}$ & Narrow & Controls in interrelated lending \\
\cline { 2 - 3 } & Broad & Oversight on managers \\
\hline $\begin{array}{c}\text { Institutional structure of banking } \\
\text { industry }\end{array}$ & & Accounting and disclosure practices \\
\hline Implicit or explicit guarantees & & Nature of safeguards to control moral \\
hazard
\end{tabular}

\section{Financial Safety Nets}

A banking system can be viewed as a public good - in that it supports economic growth through its intermediation, credit allocation, liquidity creating, and payments system services. The banking system also imposes contingent liabilities on the government in the event that it has to intervene in response to a banking crisis. A government can achieve the public good aspects and mitigate its contingent liability through imposing regulations and ensuring adequate information to strengthen market discipline on the banks. Achieving the public good aspects of the banking system will also require that the banking system is efficient, and this will generally require permitting the entry and exit of financial institutions. Moreover, the capacity of financial regulation and supervision to prevent banking problems is inevitably limited, and thus maintaining financial system stability will also require having in place a financial safety net to deal with crises, as well as the exit of financial institutions in noncrisis situations.

Financial safety nets may consist of lender-of-last-resort facilities, deposit insurance, asset protection funds in various markets, and other elements of the overall regulatory framework. Lender of last resort facilities are short-term liquidity assistance provided by the government to solvent banks facing a temporary liquidity shortage in order to avoid systemwide bank failures. Deposit insurance schemes are designed to protect small depositors from losses that may result from individual or systemic bank failures. More generally, asset protection funds are public or private arrangements to insure various asset holders against unexpected losses. These facilities and arrangements, together with elements of regulatory framework, provide a safety net for the system as a whole.

Implicit or explicit government guarantees alter the incentives facing depositors, owners, managers, and financial markets in general and thus can generate additional problems of moral hazard and adverse selection. In particular, the possibility of assistance from public funds alters the risk-return tradeoff towards greater risk-taking, reducing the overall stability of the financial system. Since depositors and creditors are insured for their 
losses, deposit insurance may reduce the incentives for depositors and creditors to monitor the behavior of financial institutions, whereas financial intermediaries may also have less incentive for prudent behavior, since they can still attract deposits and can invest the proceeds in riskier projects, secured in the knowledge that the "lender of last resort" will bear the downside risk of project failure.

Financial system stability will thus only be enhanced by a financial safety net when the regulatory framework is sufficiently well structured, comprehensive, and effective at mitigating the increased moral hazard. Elements of safety nets that can help achieve this include: building the safety net on a "tiered" early warning system supported by "staged" supervisory interventions to ensure prompt resolution of a problem institution; and clearly defined rules on the framework of central bank lender of last resort facilities but "constructive ambiguity" in the application of these facilities to specific institutions. During a crisis, the central bank should make a critical judgment based on the trade-off between contagious risks and moral hazard effects (see Goodhart and Huang, 1999). Lender-of-lastresort facilities should be restricted to solvent banks and charged at penalty rates on good collateral, but more often, the central bank may not demand collateral and not charge at a penal rate if it deems the systemic risk is very high. Concerning deposit insurance, Garcia (1996) suggests that, in normal times, the deposit insurance scheme should (i) be explicitly defined by law; (ii) resolve failed depository institutions promptly; (iii) impose limitations on coverage; (iv) have wide membership; (v) pay deposits quickly; (vi) have adequate sources of funding to avoid insolvency; and (vii) offer risk-adjusted premiums. The institutional arrangements governing deposit insurance funds should be structured so that the agency is independent and can take prompt corrective action to intervene before institutions fail.

\section{TECHNIQUES FOR ASSESSING RISKS IN THE FINANCIAL SYSTEM}

This section focuses on the methodologies used for assessing risks as reflected on and off the balance sheets of financial institutions. As discussed in the next section, these assessments constitute only part of the equation in determining financial system vulnerabilities.

\section{A. Principal Types of Financial Risks}

The principal types of risks stemming from banking activities include credit risks, liquidity risks, market risks, and operational risks:

Credit risk arises from the risk of borrower defaults, downgradings, or failures to pay on a contractual obligation. The degree of riskiness of a loan is affected by a number of factors: the general macroeconomic environment, the legal environment that determine the capacity to recover on a loan; and the existence of collateral, compensating balances as well as other relevant characteristics of the credit market such as loan covenants.

Liquidity risk occurs when a bank must make unexpected cash payments. This type of risk stems from the "demand" specificity of the demand-deposit contract that allows unexpected large withdrawals. The level of liquidity risk is a function of a bank's capacity to 
trade its portfolios in interbank and secondary markets, as well as the availability of shortterm liquidity assistance by the central bank.

Market risk loss results from changes in the market price of the bank's assets and liabilities. Examples of market risk are foreign exchange risk, interest rate risk, commodity and equity price risks, and options risk on mortgages and deposits.

Operational risk (or business risk) is the uncertainty of the revenues and expenses associated with non-portfolio activities, such as origination, servicing, and data processing. Operational risk is a function of general industry factors (e.g., new entry), company-specific factors (e.g., internal control, relation with overseas subsidiaries), and external factor (e.g., technological advances and regulatory changes).

These risks are often difficult to quantify, and more so when the interaction of different types of risk lead to systemic risks. Systemic risks affect a financial system's stability when an idiosyncratic shock to an individual financial institution generates contagious effects on others in the system. The experience with Long-Term Capital Management (LTCM) provides an example of these systemic risks. Many of LTCM's counterparts estimated their risk exposure to LTCM and the impact of its failure on their portfolios, but when LTCM rapidly liquidated its portfolio, the liquidation in different asset markets depressed the prices of other assets LTCM's counterparts held. The resulting losses were potentially much worse than initially calculated by these banks.

\section{B. Balance Sheets and Macroprudential Indicators and their Limitations}

An assessment of potential risks in the financial system generally begins with a review of the main balance sheets in the economy. This consists of the balance sheets of the financial intermediaries, as well as the balance sheets of the major sectors in the economygovernment, nonfinancial corporations, and household sectors. Such balance sheet information has to be supplemented with some key prices and macroeconomic variables.

The general types of indicators that are being developed are referred to as macroprudential indicators (MPIs) ${ }^{5}$ These include macroeconomic indicators that have been shown to precede banking crises, ${ }^{6}$ and aggregated microprudential indicators that focus on the CAMELS framework. ${ }^{7}$ Table 3 provides a summary of macroprudential indicators and indicates which indicators have been found useful in studies of banking system problems. The MPIs provide a snapshot of the state of a financial system.

\footnotetext{
${ }^{5}$ For a discussion of macroprudential indicators and their use in vulnerability assessments, see Hilbers and others (forthcoming 2000).

${ }^{6}$ For a systematic analysis of macroeconomic vulnerability indicators for crises, see Berg, et al. (2000).

${ }^{7}$ The CAMELS framework involves the analysis of six groups of indicators: Capital adequacy, Asset quality, Management soundness, Earnings, Liquidity, and Sensitivity to market risk.
} 
Table 3. Possible Macroprudential Indicators

\begin{tabular}{|c|c|}
\hline Microprudential Indicators & Macroeconomic Indicators \\
\hline Capital adequacy & Economic growth \\
\hline Aggregate capital ratios* & Aggregate growth rates* \\
\hline \multicolumn{2}{|l|}{ Aggregated risk-based capital ratios } \\
\hline Equity as a percent of capital & $\begin{array}{l}\text { Sectoral balance sheets } \\
\text { (a) Households }\end{array}$ \\
\hline Asset quality & Net financial wealth \\
\hline (a) Lending institution & Financial liabilities as a percentage of gross \\
\hline Sectoral credit concentration* & wealth \\
\hline Non-performing loans* & (b) Corporations \\
\hline Provisions as a percent of nonperforming loans & Debt to equity ratios \\
\hline Connected lending & Net worth \\
\hline \multicolumn{2}{|l|}{ Off balance sheet exposures } \\
\hline (b) Borrowing entity & Balance of payments \\
\hline Debt-equity ratios & Current account deficit \\
\hline Corporate profitability & Foreign exchange reserve adequacy \\
\hline Household indebtedness & $\begin{array}{l}\text { External debt (including maturity structure) } \\
\text { Terms of trade* }\end{array}$ \\
\hline \multirow[t]{2}{*}{$\begin{array}{l}\text { Management soundness } \\
\text { Expense ratios }\end{array}$} & Composition and maturity of capital flows \\
\hline & Inflation \\
\hline Earnings/profitability & Volatility in inflation* \\
\hline \multicolumn{2}{|l|}{ Return on assets } \\
\hline Return on equity & Interest and exchange rates \\
\hline Income and expense ratios & $\begin{array}{l}\text { Volatility in interest and exchange rates* } \\
\text { Level of domestic real interest rates }\end{array}$ \\
\hline Liquidity & Exchange rate sustainability \\
\hline Central bank credit to financial institutions* & Exchange rate guarantees \\
\hline \multicolumn{2}{|l|}{ Deposits in relation to monetary aggregates* } \\
\hline Loans-to-deposits ratios & Lending and asset price booms \\
\hline Liquid asset ratios & Lending booms \\
\hline Measures of secondary market liquidity & Asset price booms \\
\hline \multicolumn{2}{|l|}{ Indicators of segmentation of the money market } \\
\hline Sensitivity to market risk & $\begin{array}{l}\text { Contagion effects } \\
\text { Financial market correlations* }\end{array}$ \\
\hline Foreign exchange exposure* & Trade spillovers \\
\hline \multicolumn{2}{|l|}{ Interest rate and maturity mismatching } \\
\hline & Other factors \\
\hline Market-based indicators & Government recourse to the banking system* \\
\hline Stock market index* & Arrears in the economy \\
\hline \multicolumn{2}{|l|}{ Equity prices of financial institutions } \\
\hline \multicolumn{2}{|l|}{$\begin{array}{l}\text { Interest rate spreads on borrowing by financial } \\
\text { institutions }\end{array}$} \\
\hline \multicolumn{2}{|l|}{ Credit ratings } \\
\hline \multicolumn{2}{|l|}{ Sovereign yield spreads } \\
\hline \multicolumn{2}{|l|}{ Financial market structure } \\
\hline \multicolumn{2}{|l|}{ Concentration ratios in the banking scctor } \\
\hline Number of financial institutions & \\
\hline
\end{tabular}

Source: Hilbers and others (2000).

*Denotes indicators that have been found useful in empirical studies of banking system problems. 
A number of substantial analytical and statistical issues still need to be resolved with the use of MPIs. Among the data problems are the diverse accounting standards across countries; failure of many accounting records to reflect current conditions; poor information on the quality of banks' claims; lack of information on holdings of financial derivatives; limited availability of financial information on nonbank financial institutions and the nonfinancial sectors of an economy; and absence of sectoral balance sheets on the nonfinancial, corporate and household sectors. The problems of confidentiality, off-balancesheet, and derivative transactions are particularly serious limitations since the balance sheets will not reveal the economic exposures that are relevant when assessing vulnerabilities. Unlike the stress-testing approach, discussed below, MPIs do not inform the likely outcome from a shock, and the interpretation and predictive role of MPIs remains a matter for further study.

\section{Risk Measurement Models}

Risk models are statistical tools used to measure risk. Risk is defined by the banking profession as those potential losses that can be suffered by a financial institution within some confidence interval. Once the potential losses are estimated, they can be related to the available capital in order to establish the adequacy of the financial institution's capital to the level of risk undertaken. ${ }^{8}$ Risk models are superior to risk indicators since risk indicators only provide evidence of the existence of risk but are unable to quantify it. A bank can be viewed as a portfolio of assets and liabilities (long and short positions). The value of this portfolio is the bank's equity, i.e., quantify it, whereas risk models quantify potential losses and establish the bank's capital adequacy

$$
\mathrm{E}=\sum_{i} x_{i} p_{i}-\sum_{j} x_{j} p_{j}
$$

where:

E: bank equity;

$\mathrm{p}_{\mathrm{i}}$ : value of the bank asset $\mathrm{i}$.

$\mathrm{p}_{\mathrm{j}}$ : value of the bank liability $\mathrm{j}$.

$x_{i}$ and $x_{j}$ number of assets $i$ and liabilities $j$ in the bank portfolio

Most risk models are concerned with valuing this portfolio under different scenarios and circumstances.

\footnotetext{
${ }^{8}$ The Basle Committee recommended 8 percent risk capital ratio is in fact a simple model of risk measurement that assumes that potential losses due to credit risk amount to 8 percent of the face value of bank assets. Under some circumstances, the potential losses are expected to be lower and, as a consequence, the capital requirement is reduced (e.g., in the case of mortgage loans the potential losses are estimated to be 4 percent, i.e., $0.50 \times 0.08$ ).
} 
There are several risk-measurement models available to the risk manager or to the regulator, such as duration, VaR models applied to market and credit risk, models based on option theory, and models based on insurance techniques. This section provides a short overview of the most important risk measurement models that have been publicly disclosed.

\section{Duration}

Duration is a model that can be used to quantify potential losses due to changes in interest rates. The technical derivation is provided in the appendix. The main advantage of a duration approach is its simplicity and relatively low data requirement. The main disadvantages are: (i) duration is only a first-order approximation to interest rate risk. Since the relationship between the value of assets and interest rates is highly nonlinear, this approach is not suitable for very large interest rate shocks (above 1 percent); (ii) duration assumes that the term structure moves in a parallel fashion (i.e., all interest rates go up or down by the same amount) and consequently disregards spread risk; and (iii) duration only applies to interest rate risk and ignores the correlations with other forms of risks and the correlations between changes in different yields.

\section{VaR Models}

VaR models improve over duration models with respect to all the limitations discussed above. They were first used to measure market risk ${ }^{9}$ in the trading book and then extended to credit risk.

\section{VaR and market risk}

The VaR of a portfolio can be defined as:

(1) $\quad \mathrm{VaR}=$ (Value of the portfolio when the vector of prices is $\mathbf{P}-$ Value of the portfolio priced at today's prices) $* \sqrt{T}$

where: $\mathbf{P}$ is a vector of future prices such as foreign exchange rates, interest rates, commodities, equities, predicted within some confidence interval (typically 95 percent or 99 percent); and $\mathrm{T}$ is the number of days it takes to undo the positions in the portfolio. $\mathrm{T}$ can go from 1 day for very liquid positions to several days in the case of very illiquid markets. ${ }^{10}$

Two important issues arise when analyzing a VaR methodology for market risk: (i) how to map the different positions, i.e., how to decompose transactions into building

\footnotetext{
${ }^{9}$ VaR can also be used to measure market risk in the banking book. The first VaR model made publicly available was http://www/riskmetrics.com in 1994.

${ }^{10}$ This liquidity factor adjustment is based on the assumption that prices are random walk. If the VaR specification is not linear, or the liquidity factor is different for each position, the adjustment should be done independently for each position.
} 
blocks so that they can be aggregated and repriced using the predicted prices; and (ii) how to predict future prices.

The first issue has been successfully addressed by the theory of financial instruments and there is consensus on how to do it in most cases, provided that the transactions are known in detail. Positions can go from a simple holding of a bond to complex derivative products. Given the ability of banks to undo their positions and get into new ones and the high daily price volatility, $\mathrm{VaR}$ is usually measured on a daily basis. ${ }^{11}$

The second issue is more debatable and different approaches to it give rise to different VaR models. There are three basic approaches: (i) variance-covariance; (ii) historical simulation; and (iii) MonteCarlo simulation:

The Variance-Covariance approach is based on the assumption that changes in prices can be modeled as (multi)normally distributed. From the properties of the normal distribution, the worst move in price that can take place within a 99 percent ( 95 percent) confidence interval is equivalent to 2.33 (1.65) standard deviations. Consequently, the VaR for a single position is defined as:

$\mathrm{VaR}=$ Value of the position today $\times 2.33(1.65)$ standard deviations

The advantage of this model is its simplicity and analytical tractability. Its main drawbacks are: (i) the distribution of changes in prices have been found to have tails that are fatter than predicted by the normal distribution; and (ii) this approach cannot be applied to non-linear positions (such as derivatives).

The Historical simulation approach uses the past history of changes in prices to price today's positions. If the time series has 250 changes in prices, then the portfolio is repriced 250 times. The lowest possible value obtained for the portfolio, within a 99 percent (or a 95 percent) confidence interval, is then plugged in (1) and the VaR computed. The advantages of this method are the following: (i) it is distribution-free; and (ii) it can be applied to nonlinear positions. Its main disadvantage is that predictions depend on the chosen history .

The Monte-Carlo simulation approach uses a simulated series of changes in prices to recalculate the value of the portfolio and then computes the worst value within a given confidence interval. Its main advantages are: (i) it allows to use any distribution as the base for the simulations; and (ii) it can be applied to non-linear positions. Its main disadvantage is its computational cost.

\section{VaR and credit risk}

VaR models have also been applied to credit risk. Within a credit risk framework, VaR models attempt to model the distribution of future changes in the value of a portfolio of

\footnotetext{
${ }^{11}$ Some banks also do intra-day VaR follow-up.
} 
bonds or loans (that are subject to credit risk), within some confidence interval. ${ }^{12}$ The VaR definition above is still valid for this type of $\mathrm{VaR}$, with two qualifications: i) the term structure of risky securities is now explicitly included within the vector $p$ in order to be able to assess the losses due to downgrading; ii) the value of a defaulted security is given by its recovery value net of transaction costs. ${ }^{13}$

An important input in VaR models applied to credit risk is the credit transition matrix. Some VaR models, such as CreditMetrics by J.P. Morgan, use historical transition matrices (e.g., the probability of a BBB bond becoming a BB bond is based on the number of times that $\mathrm{BBB}$ bonds were downgraded to $\mathrm{BB}$ bonds in the past). The advantage of using a historical transition matrix is its simplicity. There are also disadvantages: (i) a historical credit transition matrix does not depend on the state of the economy (e.g., the probability of default is predicted to be the same during a cyclical downturn or in an upturn, during a period of low or high volatility, etc.) ${ }^{14}$ and (ii) most countries do not have historical records of downgradings or defaults, and, as a consequence, historical transition matrices cannot be estimated.

The VaR model applied to credit risk developed by Ted Barnhill is based on a credit transition matrix that depends on the state of the economy, i.e., the Barnhill approach allows the estimation of stochastic credit rating transition matrices. The crucial variable that relates the bank corporate client creditworthiness to changes in prices (the financial environment) is the corporation's debt-to-equity ratio under each possible state of the economy. Debt-to-equity ratios are related to the state of the economy through the client's betas. ${ }^{15}$ Apart from the estimate of risk in the corporate portfolio, the Barnhill model allows to estimate the risk of a portfolio of mortgage loans. ${ }^{16}$

${ }^{12}$ They can also be applied to measure the credit risk of a portfolio of derivatives.

${ }^{13}$ The value of a security in a state in which it was downgraded is the value of its stream of cash-flows, discounted by the (forward zeros) that correspond to the term structure of the lower credit category. The value of a defaulted security is its recovery value net of transaction costs.

${ }^{14}$ If enough data were available, one could estimate one transition matrix based on defaults and downgradings that took place during a period of recession and another one based on a boom period data.

${ }^{15}$ The "beta" is the parameter that relates changes in the value of the market portfolio (e.g., given by the all-stock index traded in the stock exchange) to the return of the individual stock (i.e., the systematic risk). This is a one-factor model. McKinsey \& Company has developed a multi-factor model. In the context of the Capital Asset Pricing Model, the return on a security is given by its systematic risk and its specific risk.

${ }^{16}$ The variable that relates the value of the mortgage loan to the financial environment is the loan-to-value ratio, i.e., the ratio of the remaining face value of the loan to the value of the property that is used as collateral. 


\section{Other modeling approaches}

\section{Extreme value theory}

Extreme value theory has challenged VaR models in the case of market risk. Extreme value theory models the tail of the distributions of changes in prices and deals mainly with the prediction of extreme (or beyond VaR) outcomes. ${ }^{17}$ Born in the insurance industry, extreme value approaches seem to be well prepared to address the issue of the probability of a crisis scenario.

\section{An option-approach to credit risk}

$K M V$, the California-based consulting firm, has developed a model of default prediction based on option pricing and on the availability of a large data set on defaults. Their contribution to the modeling of bank risk is given by their estimation of corporate defaults, or "expected default frequency" (EDF). From bank client (corporate) defaults, they

can then estimate the potential losses that a bank can suffer due to credit (default) risk. ${ }^{18}$

${ }^{17}$ Extreme value theory attempts to find the probability that an event $X$ takes a value greater than $x$, by estimating the parameters of a Pareto distribution. (For example, extreme value theory can answer questions of the following nature: what is the probability that the interest rate in country $\mathrm{Y}$ can be higher than 15 percent in the next month.)

${ }^{18}$ KMV base their expected default frequency in what they call the distance from default.

where:

Distance from default $=(A-B) /$ sigma

A: is today's value of the bank client assets

$B$ : is the face value of the bank client debts

Sigma: is the standard deviation or volatility of the market value of assets

If $\mathrm{A}=100, \mathrm{~B}=80$ and sigma $=10$, then the distance from default is two standard deviations. If, in addition, changes in asset values are assumed to be normally distributed, there is a 95 percent probability that asset values will vary between plus and minus 2 sigmas from their mean value. This means that there is a 2.5 percent probability that asset values will fall by more than 2 sigmas. The EDF is 2.5 percent. When a large data set is available, it is possible to estimate an empirical EDF (as an alternative to assuming normality), i.e., the percentage of firms that actually defaulted within a one-year risk horizon when their asset values placed them 2 sigmas distance away from default at the beginning of the year, $v s$. the total population of firms who were 2 sigmas away from default. Option pricing is used to estimate the value of the firm assets and the firm asset volatility. 


\section{The insurance approach}

CreditRisk Plus, by Credit Suisse Financial Products, is a credit risk model based on an insurance approach. They distinguish among three forms of uncertainly: (i) the mean default rate, modeled as a Poisson distribution; (ii) changes in the mean default rate, modeled as a Gamma distribution; and (iii) size of losses. CreditRisk Plus's measurement of credit risk is closer to a loss of earnings or book value capital measure than a full market value of economic capital measure.

\section{Evaluation of Risk Measurement Models}

In comparing different models it is important to distinguish between the usefulness of models for use by the industry and their usefulness in the assessments of risks in the financial system.

\section{Use of models by the industry}

On the use of models by the industry, for market risk (including interest rate risk in the banking book), any VaR model seems to be suitable, since these models relate in a direct way the prices (i.e., the environmental variables that are relevant to the value of a bank portfolio) to the bank positions. Duration models are too restricted since they limit the evaluation to interest rate shocks. In countries where banks are active in derivatives, a VaR based on a MonteCarlo simulation or on the past history of prices is more reliable than a simple variance-covariance approach.

For credit risk, a VaR model that can integrate market and credit risk would be a useful instrument. These models would generally include a credit transition matrix that depends on the state of the economy (such as in the Barnhill or the McKinsey approaches). In option-based models like KMV's, and CreditRisk Plus actuarial model there is no clear connection between the characteristics of the macroeconomic environment in which banks operate and bank risk.

Confidence in the model depends critically on having a sufficiently diverse data series, covering the full range of contingencies that the institution is likely to confront. Also, liquidity risk is not well-captured by the models. This has been a source of weakness in VaR methodologies, which generally assume that secondary markets would continue to provide for trading opportunities even during a crisis. A third deficiency is the model's failure to reflect the interconnectedness of banks and the assumptions used by other banks in their modeling strategies. Thus a large portion of systemic risk may not be captured by the model. For example, should banks use the same or similar testing approaches, then in order to control their losses they might decide to sell off a certain class of risky assets (and demand a certain class of liquid assets) simultaneously. As a result, the situations in the market could be worsened precipitously. Finally, after their market risk VaR models have been developed, banks can (strategically) shift to new business whose risk is not captured by the existing market risk VaR model, thus exposing them to unanticipated risks. 


\section{Use of models for assessments of financial system vulnerability}

\section{Feasibility}

There are extensive data requirements for estimating risk models, which in themselves limit the feasibility of the application of such models by external assessors. The main inputs are:

- Time series of the prices that are relevant in the definition of the country's financial environment.

- The banks' positions (e.g., number, size and types of loans, currency of denomination, timing of cash flows, interest rate, size of the derivatives book, bonds, etc).

- $\quad$ Financial characteristics of bank clients (e.g., credit quality of the client, client leverage, etc).

Time series of prices are usually publicly available. Financial institutions know their positions and in most cases they keep records on the financial characteristics of their clients. Consequently that information is also available in principle. Nevertheless, the information related to the bank positions and clients is usually regarded as extremely confidential and financial institutions may decide not to disclose it. Thus the application of such models will depend critically on the willingness of banks to disclose confidential and proprietary information. Moreover, the reliability of the information will depend on the integrity of the underlying accounting systems.

When the necessary data is not available, the assessments would generally have to be limited to evaluating the methodologies used by the banks to measure market and credit risk together with an assessment of the capability of banks' managers to properly manage risk (i.e., measure, control, and price risk). In cases in which banks are also unwilling to disclose the characteristics of their systems to manage risk, the assessments would need to focus on evaluating the banking regulations and the ability of the bank supervisory agency to monitor the risk-management process, including the banks' risk-management models, in banks under their surveillance.

\section{Usefulness}

Even where data are available, and its integrity assured, the usefulness of risk and stress testing assessments will be limited for a number of reasons.

First, the "shelf life" of risk assessments can be very short, especially as regards assessments of market risks. Since most trading positions can be undone very quickly, the potential losses due to changes in prices can vary considerably on a daily basis, in particular in the case of banks that engage in derivatives that are by definition highly leveraged transactions. The implication is that no market/credit risk assessment for the trading book will remain valid after a number of days. 
Second, although the stability of the financial system can be considered by aggregating the results of stress tests on individual institutions, stress testing is essentially a partial equilibrium analysis in that it does not take into account all of the possible interactions between financial agents for a given scenario. Thus when one institution is exposed to a shock, stress testing does not take into account the impact of that institution's response on all other agents and the possible feedback effects.

Third, risk models are at the frontier of financial engineering, and are far from providing a non-contestable treatment to all challenges posed by the measuring of risk. For example, questions remain whether risk assessments based on these value-at-risk (VaR) models, which are generally backward-looking, takes appropriate account of known structural changes that may affect price and credit risk.

\section{Need for additional research}

There are two main areas where additional research would be needed to determine the usefulness of the application of risks models in assessments of financial vulnerability:

1. Research on the methodology linking macroeconomic performance to the risks in the countries' financial environments and bank exposures. Such research could include an assessment of the role of credit transition matrices in the estimation of credit risks and the modeling of mortgages and other type of loans to individuals. Technical work could also include the treatment for the fat tails in the distributions of changes in prices, the relaxation of the constant variance and correlations implicit in the model, and the use of multivariate extreme-value theory to assess the probability of crisis; and

\section{Research on alternative methods to generate the information that may not be} available in less developed financial markets. Such research could include the researching of within- and cross-country correlations by financial variables and the creation of parameter estimates required by the model that can be then used as second best or proxy inputs in cases when the information is not available. Countries may also need to be encouraged to collect and publish more information on bank balance sheet and off-balance sheet positions.

The overall conclusion on risk-measurement models is that while risk models may provide a useful tool for analyzing potential risks facing individual institutions and the financial system, there are some inherent weaknesses in the methodology that should preclude an excessive reliance on the technique.

\section{E. Assessments by Rating Agencies}

Rating agencies provide another source of information that can be useful in assessing financial systems' vulnerabilities. Rating agency assessments include: (i) financial systems; (ii) country-specific risk; (iii) individual financial institutions; and (iv) nonfinancial institutions. Rating agencies generally have good data bases on the institutions that they rate and are a good source of cross-country and cross-institution information (e.g., Thompson Bank Watch and Fitch, IPCA). Their cross-country information sources allow for 
international companies that can compliment the assessment of financial systems' vulnerabilities that focus on an individual country.

There exist several credit rating products that attempt to give overall assessments of the soundness of the financial system. Some are descriptive in nature, summarizing recent developments in regulatory and operating framework, past profitability, and balance sheet strength. Others provide a ranking of average bank financial strength. The most ambitious products are more forward looking indicators of risk and potential cost of banking crises. In addition, rating agencies provide company-specific ratings, including financial intermediaries such as banks and insurance and securities companies. This information can be yet another source of information for assessing financial system soundness. The ratings are generally designed to provide information on the health of the institution, and on the default probability of different classes of obligations it has issued. For banks, these liabilities include banks deposits, senior and subordinated debt, and preferred stock. For insurance companies, the claim paying ability (CPA) is usually the crucial rating.

Rating methodologies differ among agencies and products, but typically take into account (i) the operating environment (competitive, regulatory, institutional support); (ii) ownership and governance; (iii) franchise value; (iv) recurring earning power; (v) risk profile (credit, market, liquidity and asset-liability management, agency, reputation, operational, etc.) and risk management; (vi) economic capital analysis; and (vii) management priorities and strategies.

The usefulness of rating agency assessments as predictors of financial difficulties remains a matter of debate; however the assessments do provide a proxy for the market assessments of the countries or institutions that are being rated. Since market sentiment is itself an important determinant of contagion and systems' vulnerabilities, a review of rating agency assessments can help identify potential contagion vulnerabilities. An issue that has arisen in some assessments is the failure of markets to distinguish significantly between individual institutions in a country, even when their activities and performance are diverging. Failure of the markets to distinguish between individual institutions could increase the risk of contagion in the financial systems from institution-specific events.

\section{SUPERVISORY ASSESSMENTS AND SYSTEMIC VULNERABILITIES}

This section examines and evaluates the role of the assessment of supervisory arrangements in identifying financial system vulnerabilities, and proposes an approach to assessing systemic vulnerabilities in the financial system.

Supervisory arrangements are generally designed to provide oversight on the business activities of financial institutions, specifically: (i) the adequacy of financial institutions management, and their internal procedures and arrangements for controlling risks; and (ii) their compliance with legal and regulatory requirements, including minimum prudential requirements. A review of supervisory arrangements as part of an assessment of financial vulnerability will generally entail an assessment of the adequacy of: 
1. The legal and regulatory framework for financial institutions (banks, insurance, nonbank deposit-takers and securities firms), financial markets (securities and organized derivative markets), and payments and settlement systems (particularly the systematically important large-value transfer systems and securities settlements). Generally this entails a description of the nature of the legal and regulatory framework, and an assessment identifying any specific gaps or weaknesses;

2. The supervisory arrangements - generally a review of the adequacy of the minimum prudential standards (e.g., solvency, minimum capital, reserving and provisioning requirements), the procedures for oversight of institutions and suitability of these arrangements to the types of risks confronting the financial system, and measures for dealing with specific risk areas, and responding to problems in financial institutions when they occur; and

3. Coordination between different regulatory agencies to address issues of the adequacy of coverage of the financial regulatory and supervisory system, and to identify any gaps in the regulatory framework that could result from the adoption of different approaches to supervision by different regulatory agencies (including banking, insurance, and securities).

\section{A. Role of Assessments and Standards}

The assessment of the compliance with standards developed by the main international groupings of supervisors covering banking and payments (Basel Committee), insurance (IAIS), and securities (IOSCO) is an important element of these supervisory assessments. The standards and codes promulgated by the major international regulatory bodies provide critical benchmarks and objective standards to assess the supervisory arrangements. In some cases the supervisory bodies have developed detailed assessment methodologies. The standards, therefore, help to establish uniform benchmarks for the assessments, and as such reduce information asymmetries and promote effective policymaking. First, where the compliance assessments are made public, they expand the range of information available to all participants. Second, the standards assessments encourage the adoption of a minimum level of conduct or regulatory oversight, and can help to promote financial stability.

Analysis is still someway off, however, in linking standards assessments with potential vulnerabilities in the financial system. This reflects not only the recentness of most standards initiatives, but also a recognition that standards assessments will often not go far enough to identify the specific vulnerabilities in financial systems. A check list of system compliance with minimum regulatory standards will often not reveal the effectiveness of implementation of the regulations, nor their role in managing the risks inherent in the financial system. The material implications of noncompliance with standards also has to be assessed in the context of the country's particular circumstances, and would depend on factors such as the sophistication of the country's financial system, the ownership structure and the prevalence of certain types of transactions. In some cases, supervisory arrangements may also need to go beyond compliance with standards to address the risks confronting the financial systems (e.g., the IAIS Principles do not cover complex derivative products). Assessment of vulnerabilities will generally have to be more intrusive and more selective than implied by assessments of standards compliance. 


\section{B. Methodology for Assessing Financial System Vulnerabilities}

An assessment of vulnerabilities in the financial system will generally require a comparison of the supervisory system with the nature of the risks confronting the financial system (as reflected by the outcome of the assessments described in the two preceding sections). For this purpose we have introduced the concept of "net risk." Net risk or vulnerability could be defined in as:

\section{Net risk (vulnerabilities) $=$ Gross risks minus the adequacy of the risk management/supervisory system}

The basic concept is that in assessing vulnerabilities, the adequacy of the supervisory system has to be tested against the risks confronting the financial system (rather than for compliance with international standards).

The concepts in the above net risk formulation are difficult to measure, and more so when allowance is made for more complex financial systems. Ongoing innovations in financial systems, including the growing importance of off balance sheet and derivative transactions have generally made it more difficult for external evaluators to measure and assess risks (as discussed in the previous chapter.) As financial systems become more sophisticated, greater reliance has thus to be placed by the supervisory authority on an assessment of the adequacy of management and internal controls in the financial institutions rather than their direct assessments of the risks. The "net risk" equation discussed above, would have to be modified to involve a comparison of the risk environment with the modalities for exercising oversight over the financial system:

\section{Net risk (vulnerabilities) $=$ Riskiness of the environment minus effectiveness of the modalities for exercising oversight.}

An assessment of the riskiness of the environment would include, for example, the nature of the transactions being entered into, the nature of their counterparties, the nature of the markets in which their transactions are conducted, and the nature of the ownership and incentive structures confronting the main financial market participants. An assessment of the modalities for oversight would include a review of the methodologies applied by the supervisory agency in assessing and controlling risks, and whether the supervisory skills and techniques are appropriate to the nature of the transactions conducted by financial institutions.

More generally, it may be useful to assess vulnerabilities in the context of the following systemic vulnerability matrix. In this matrix, risk and riskiness of the environment are plotted on the vertical axis, and the effectiveness of the risk management systems and systems of oversight on the horizontal axis: 
Figure 1. Systemic Vulnerability Matrix

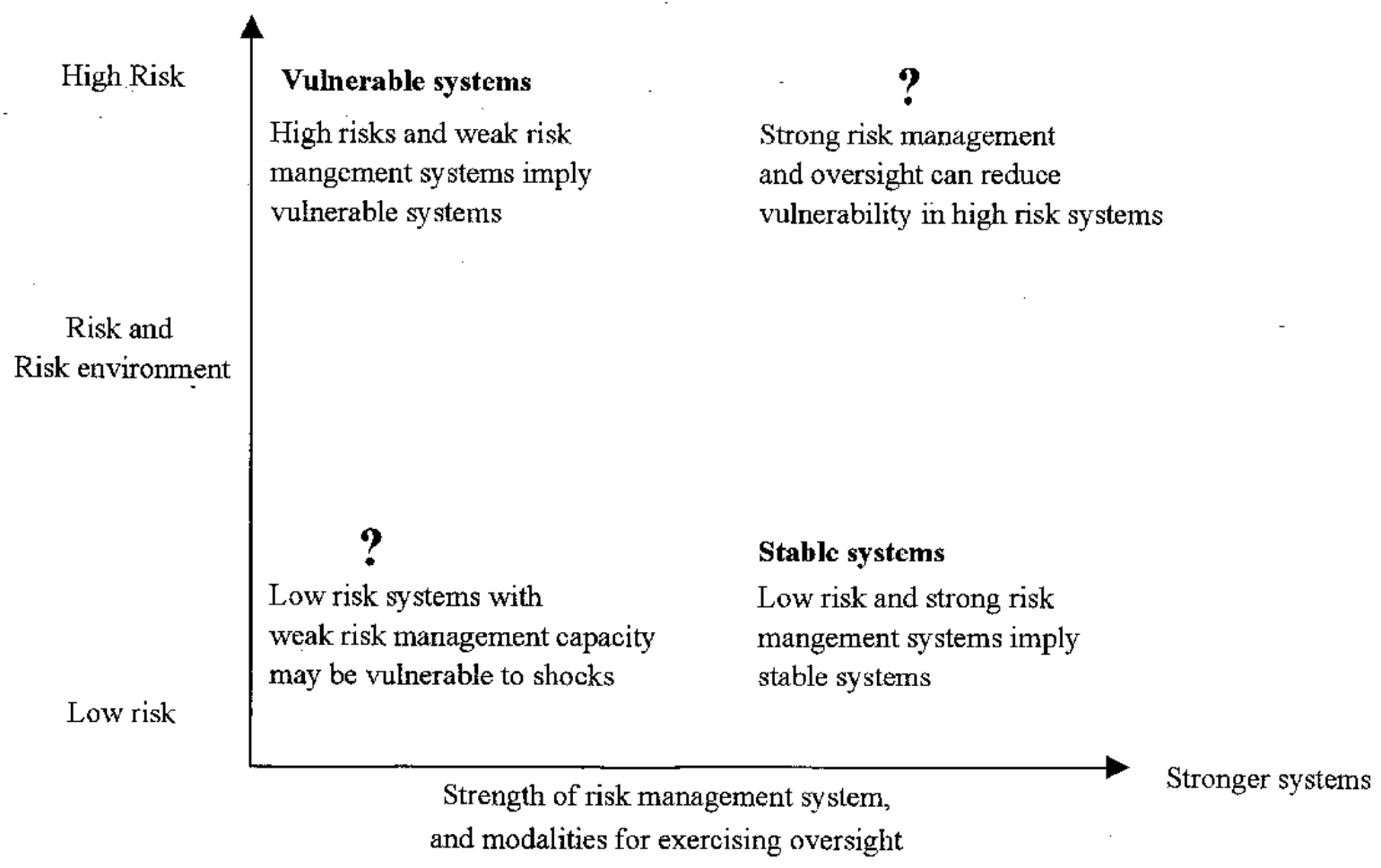

Analyzing systems in terms of this matrix can help distinguish vulnerable from stable systems. However, it also serves to highlight that in many systems an assessment of vulnerability will require a judgement on whether the strength of the risk management systems are adequate to deal with the potential risks in the system. The key issue for systemic vulnerability is not whether institutions can take on more risk, but whether they and the financial system are able to manage these risks.

Examples of where this approach is relevant include:

1. The treatment of market risks where banks rely increasingly on internal value at risk models to mange risk exposures, and supervisory agencies have been willing to validate their internal risk models for the purpose of determining regulatory capital standards for market risks. The VaR models, if applied appropriately, can help banks to control and manage risk, and equally they can help financial regulators to more effectively monitor the risk levels in the portfolios of banks and other financial institutions so that prompt regulatory actions can be taken. A supervisory assessment would focus on the modalities used by the supervisor to assess and validate VaR models. It would also take account of potential strengths and weaknesses of such models in handling risks.

2. Review of optimal capital ratios. Optimal capital ratios may need to be assessed against the background of the economic and institutional environment. Lower minimum ratios could promote a higher rate of bank failure and bank entry, but may not be a source of vulnerability where the mechanisms for handling entry and exit (the financial safety nets) are 
well developed. On the other hand, higher minimum capital ratios may be appropriate in banks that are "too big to fail" or could have systemically important consequences. Higher ratios maybe desirable, for example, in countries with highly concentrated banking systems. There may be cases where it would be desirable to apply minimal capital assets ratios in a countercyclical manner, with higher ratios during boom periods in anticipation of future losses, and lower ratios during busts when losses have been absorbed in the balance sheets of institutions. Questions also arise as to whether capital adequacy should be assessed against the flexibility of the policy mix to counter economic shocks. ${ }^{19}$

3. Assessment for risk concentrations: The correlation of risk across asset classes is typically accounted in the supervisory framework in a legal rather than an economic manner. Limits are usually set for credit concentrations on a consolidated basis to a single borrower or a related group of borrowers. However, what matters economically are concentrations of credit exposures whose returns are highly positively correlated, and this may require extending concentration assessments to sectors.

4. Review of prudential regulations: For example, the failure to control lending to interrelated entities is likely to be of much greater concern for potential vulnerabilities in the financial system in a country where there are heavy concentrations of ownership of financial institutions (e.g., family ownership of banks) than in countries where bank ownership is widely held.

\section{CONClusions AND DIRECTIONS FOR FURTHER RESEARCH}

\section{A. Conclusions}

The identification of potential vulnerabilities in the financial system will generally require combining elements of the different methodologies: an analytical framework for considering the nature of potential vulnerabilities, and the underlying causes of instability based on economic theory; risk assessment techniques to quantify the extent of potential threats to financial stability; and a supervisory approach that assesses the adequacy of the legal, regulation, and supervisory arrangements. These different assessments should be combined as a systemic vulnerability assessment.

The different assessment methodologies are complementary. The economic assessments are intended to provide an overall context against which to assess financial system stability by focusing on the fundamentals - the incentive structure - that determine agents' behavior. Such assessments generally have a longer time perspective, and focus on

\footnotetext{
${ }^{19}$ For example, consider the entry of countries into EMU. The loss of an independent monetary policy puts the burden of stabilization on fiscal policy, which has historically been a less flexible instrument. On the other hand, monetary union reduces the risk from exchange rate fluctuation, at least against other EMU countries. Optimal regulation should weigh the implications of these changes in the risk environment for setting the minimum capital standards.
} 
structural features such as bank ownership, the industrial organization of banking, the legal structure, and the nature and design of financial safety nets. Risk assessments in contrast help identify near-term vulnerabilities largely through an analysis of statistical information; the quality of these assessments depends on the methodologies applied and the quality of data. Supervisory assessments including assessments of standards compliance, help to provide benchmarks on the adequacy of the supervisory and regulatory framework. Systemic vulnerability assessments serve to compare the nature of the risks and the risks environment with the capacity of the system to manage these risks.

\section{B. Directions for Further Work}

Based on the above framework we can suggest a number of possible fruitful areas for further work that could help strengthen financial system vulnerability assessments.

\section{Including explicit assessment of "net risks" as part of evaluations of financial} system vulnerabilities. Section IV introduces the concept of "net risk" as the relevant variable and the use of a systemic vulnerability matrix for assessing vulnerabilities in the financial system. Net risk is arrived at by comparing the risks (riskiness of the environment) with the adequacy of the risk management/supervisory systems (efficiencies of the modalities for exercising oversight). An assessment of "net risk" is already implicit in the overall financial stability assessment contained in the FSSAs prepared by the Fund as part of its pilot project.

An assessment of "net risk" could provide a formal way to organize an assessment of financial system vulnerabilities. The assessment would first have to compile an inventory of the principal risks confronting the financial system, with some indication of the relative importance of these risks. For example, the risks could be ranked from top to bottom on the page, with the most serious at the top. Such a ranking would clearly depend on country specific circumstances. Next, these risks would be compared with the adequacy of the system to manage these risks. The capacity of the financial system to manage the risks could be listed in the second column of the page. A third column could provide an assessment of the net risk in each case by comparing the nature of the risk and the capacity for management. This approach could help promote a comprehensive and focused analysis on risks, risk management systems, and vulnerabilities in financial system assessments.

\section{Elevating attention to an audit of incentive structures in assessing financial} system vulnerability. Currently regulatory frameworks and practices do not take account of incentive structures in any systematic way. However, an understanding of incentive structures under which financial systems operate is likely to be a critical determinant of the robustness and potential vulnerability of the financial system.

One way of evaluating structural factors affecting the incentives for risk-taking in the financial sector, would be to include a report, or what would essentially be an audit of incentive structures as part of the assessment of vulnerability in the financial system. Such an audit could be built on a checklist of features similar to those considered in this notecontract design, banking powers, banking relationships, structure of ownership and liabilities, industrial organization, existence of guarantees, and the adequacy of safety nets. The audit 
could proceed in a sequential manner focusing first on an initial list of factors that economic theory and experience indicates would influence the incentive structures in financial systems, followed by a targeted assessment of whether these would result in vulnerabilities in the financial system. The aim of the report would not be to endorse any particular structural feature, but to offer a systematic framework based on research on what incentives are generated by applicable structural features and how the regulators and other authorities have dealt with them. Such an "audit" of incentive structures would fit in and could be part of the evaluation of "net risk" discussed above.

\section{Developing methodologies for linking risk exposures with macroeconomic}

performance. It would be desirable to research how financial sector risk can be linked to macroeconomic performance. A particular issue for a research agenda would be how to handle the likely limitations in the availability of institution and bank specific data in country specific cases. An approach that could be followed in this regard would be to develop proxy information sets based on cross-country experiences. Thus cross-country research could help define, for example, the credit transition matrices that would apply at different stages of the economic cycle and at different stages of economic development. Research is also needed at a more basic level on what balance sheet and other statistical information would be crucial as part of any financial stability assessment. 


\section{DURATION MODELS}

Duration is a model that can be used to quantify potential losses due to changes in interest rates.

The sensitivity of this portfolio to interest rate changes can be estimated by deriving (1) with respect to the interest rate. We perform first the exercise with respect to a single asset, $\mathrm{P}$, whose price is given by the present value of its future cash flows:

$$
P=\sum_{t=0}^{T} \frac{x_{t}}{(1+r)^{t}}
$$

where:

$$
\begin{aligned}
& \mathrm{P}=\text { is the price of the asset; } \\
& \mathrm{x}_{\mathrm{t}}=\text { is the cash flow paid by the asset in time } \mathrm{t}
\end{aligned}
$$

Deriving with respect to the interest rate and rearranging, we have:

$$
\frac{d p}{d r} \frac{(1+r)}{P}=-\sum_{t} t \frac{\frac{x_{t}}{(1+r)^{t}}}{P}=- \text { Duration }
$$

According to (3) duration is not only a measure of the sensitivity of an asset price to interest rate changes (the left side) but also the weighted average of the maturities of the cash flows, where the weights are given by the (present) value of the cash flows as a proportion of the total value of the asset. The negative sign indicates that an increase (decrease) in interest rates is related to an asset price decrease (increase).

Alternatively,

$$
\frac{d p}{P}=- \text { Duration } \frac{d r}{(1+r)}=- \text { Duration } * \text { interest rate shock }
$$

The interpretation of (4) is that the change in the price of an asset is given by the negative of the duration of the assets time the interest rate shock. Next, we apply this derivation to a bank's capital.

Deriving (1) with respect to the interest rate and rearranging:

$$
\begin{aligned}
& \mathrm{dE}=-\left[\sum_{i} x_{i} p_{i}\left(d_{i}\right)-\sum_{j} x_{j} p_{j}\left(d_{j}\right)\right] * \frac{d r}{(1+r)} \\
& d E=-[\text { duration } \cdot \text { gap }] *(\text { int erest } \cdot \text { rate } \cdot \text { shock })
\end{aligned}
$$

The meaning of (5) is that a an increase (a decrease) in interest rates will reduce (increase) the value of bank capital when the duration gap is positive (negative). Since in most cases banks have positive duration gaps, increases in interest rates are viewed as bad scenarios for banks. 


\section{SELECTED LIST OF REFERENCES}

Allen, F. and D. Gale, 1999, Comparing Financial Systems, (Cambridge, Massachusetts: MIT Press), forthcoming.

Allen, Franklin, and Douglas Gale, 1999, "Financial Contagion," Journal of Political Economy, forthcoming.

Berg, Andrew, Eduardo Borensztein, Gian Milesi-Feretti, and Catherine Pattill, 2000, Anticipating Balance of Payments Crises-The Role of Early Warning Systems, IMF Occasional Paper No. 186 (Washington: International Monetary Fund).

Bernanke, Benjamin, 1983, "Nonmonetary Effects of the Financial Crisis in the Propagation of the Great Depression," American Economic Review, Vol. 73, pp. 257-76.

Bikhchandani, S. and others, 1992, "A Theory of Fads, Fashion, Custom, and Cultural Change as Informational Cascades," Journal of Political Economy, Vol. 100, No. 5, pp. 992-1026.

Chari, V. V. and R. Jagannathan, 1988, "Banking Panics, Information, and Rational Expectations Equilibrium," Journal of Finance, Vol. 43, No. 3, pp. 749-61.

Crockett, Andrew, 1997, "Why is Financial Policy a Goal of Public Policy," in Maintaining Financial Stability in a Global Economy: A Symposium, sponsored by the Federal Reserve Bank of Kansas City at Jackson Hole, Wyoming August 28-30, 1997.

Devenow, A. and I. Welch, 1996, "Rational Herding in Financial Economics," European Economic Review, Vol. 40, pp. 603-615.

Diamond, Douglas, and Phillip Dybvig, 1993, "Bank Runs, Liquidity, and Deposit Insurance," Journal of Political Economy, Vol. 91, pp. 401-19.

Diamond, Douglas, and Raghuram G. Rajan, 1998, "Liquidity Rish, Liquidity Creation and Financial Fragility: A Theory of Banking,"(Chicago: University of Chicago).

Garcia, Gillian, 1996, "Deposit Insurance-Obtaining the Benefits and Avoiding the Pitfalls," IMF Working Paper 96/83 (Washington: International Monetary Fund.

Goodhart, Charles A.E., and Haizhou Huang, 1999, "A Model of the Lender of Last Resort," IMF Working Paper 99/39 (Washington: International Monetary Fund), and FMG Discussion Paper 313 (London: London School of Economics). 
Hilbers, Paul, and R. Krueger, and others, 2000, Macroprudential Indicators and Data Dissemination, IMF Occasional Paper, (Washington: International Monetary Fund), forthcoming.

Jackson, Patricia and others, 1999, "Capital Requirements and Bank Behaviour: The Impact of the Basle Accord," Working Paper No. 1, Basle Committee on Banking Supervision Working Papers, April, Basle Committee on Banking Supervision, Basle, available via Internet: http://www.bis.org/publ/bcbs wp1.pdf.

Lindgren, Carl-Johan, Gillian Garcia, and Matthew I. Saal, 1996, Bank Soundness and Macroeconomic Policy (Washington: International Monetary Fund).

Masson, Paul R., 1999, "Multiple Equilibria, Contagion, and the Emerging Market Crises," MF Working Paper 99/164 (Washington: International Monetary Fund).

Mishkin, Frederick S., 1992, "Anatomy of a financial crisis," Journal of Evolutionary Economics, Vol. 2, pp. 115-130.

Stiglitz, J. and X. Weiss, 1981, "Credit Rationing in Markets with Imperfect Information," American Economic Review, Vol. 71, pp. 343-410.

Welch, I., 1992, "Sequential Sales, Learning and Cascades," Journal of Finance, Vol. 47, No. 2, pp. 695-732.

Zwiebel, J., 1995, "Corporate Conservatism and Relative Compensation," Journal of Political Economy, Vol. 103, No. 1, pp. 1-25. 